\title{
Use of Information and Communication Technologies in Natural Calamities by Residents in a Flood-Prone Community: A Case in Leyte, Philippines
}

\author{
Ma. Victoria Stephane G. Asio and Editha G. Cagasan \\ Department of Development Communication Visayas State University, Baybay City, \\ Leyte, 6521-A Philippines
}

\begin{abstract}
Residents in disaster-prone areas use information and communication technologies (ICTs) to cope with risks. This study was conducted in a floodprone barangay of Palo, Leyte to determine the informants' use of ICTs in natural calamities. Following the grounded theory approach, the 23 informants were chosen using snowball sampling and were interviewed using an in-depth interview guide. The theoretical model generated from the data showed that in this flood-prone community, residents are exposed to various information sources that they use in the different phases of the disaster for various reasons. Although informants' reasons for accessing and using ICTs were not primarily related to their use in times of disasters, their good access to these technologies proved useful in times of calamities. ICTs have also proven as crucial means of communication especially in giving residents warnings of an incoming disaster and in surviving and recovering from the disaster. Results suggest the need to enhance ICT access among residents and officials in disaster-prone communities.
\end{abstract}

Keywords: Mobile phones, Disaster response, Risk Communication, Community communication 


\section{INTRODUCTION}

Over the years, the Philippines has experienced a number of natural disasters. Zschau and Kuppers (2003) cited a study conducted by the Centre of Epidemiology for Disasters (CRED) showing that the Philippines is among the world's most disaster prone countries. The occurrence of these natural disasters is attributed to the Philippine archipelago's geological characteristics and geographical location.

The Philippine government has been implementing programs to reduce and manage risks from natural calamities. However, as seen in previous disasters that occurred in the country (e.g. magnitude 7.2 Bohol earthquake and super typhoon Haiyan both in 2013), many lives and properties were lost. Some sectors blame this to the poor communication systems in various parts of the country which in turn results in poor disaster management systems. It has been widely observed that some community residents, particularly those living in rural areas, lack access to communication devices including mobile phones and computers, the reason why it becomes difficult for them to mobilize or call for help. This lack of access is attributed to residents' language illiteracy and inadequate finances to obtain such technologies (Huang, Chan, and Hyder, 2010). The availability and accessibility of information communication technologies (ICTs) to people in disaster prone areas may thus help minimize damage to properties and loss of lives during times of disasters.

However, even with the advent of ICTs, many government organizations in the Philippines still face the challenges of minimizing disaster risks in poor and rural communities. Because of lack of access to appropriate technologies, they fail to recognize the importance of information and communication in disaster situations. This situation, according to Gunawardene and Noronha (2007), calls for more strategic and collaborative approaches in preparedness and response among governmentagencies.

Some studies on ICTs tried to find out its importance in agriculture (Alviola and Cagasan, 2008; Federicos and Gravoso, 2012), and education (Chen and Huang, 2012; Neyland, 2011). In the literature, however, it appears that less is done on the use of ICTs in risk management by residents in vulnerable rural communities. There is, therefore, a need for studies that can shed light on how these communities use ICTs as mechanisms for disaster preparedness and for coping with the risks of the disasters. Results of such studies may be used as basis in formulating government policies to 
enhance use of ICTs in natural disasters and to include ICTs as one of the priorities in any disaster risk management programs.

\section{RESEARCH METHODS}

The study was conducted in Barangay Cogon, Palo, Leyte. This site was chosen because it experiences several flooding occurrences in a year due to its location, being near the mouth of the large Binahaan River (Fig.1 \& 2). This means that much of the water collected in the entire watershed during heavy rains or typhoons passes through the mouth of the river resulting in flooding of its banks. The dangerous location of the barangay on the outside bend (meander) of the river puts it in the flow direction of the upsurging flood water. The flooding risk is aggravated by the opening of the dams operated by the Leyte Metro Water District upstream in the municipalities of Hinabangan, Dagami, Tingib and Pastrana during typhoons. This is to avoid damage to the dams and cause catastrophic flash floods in the nearby lowlands.

The severe devastation caused by super typhoon Haiyan (locally known as "Yolanda") in November 2013 clearly shows the high vulnerability of the community not only to flooding but to storm surges as well (Figure 3).

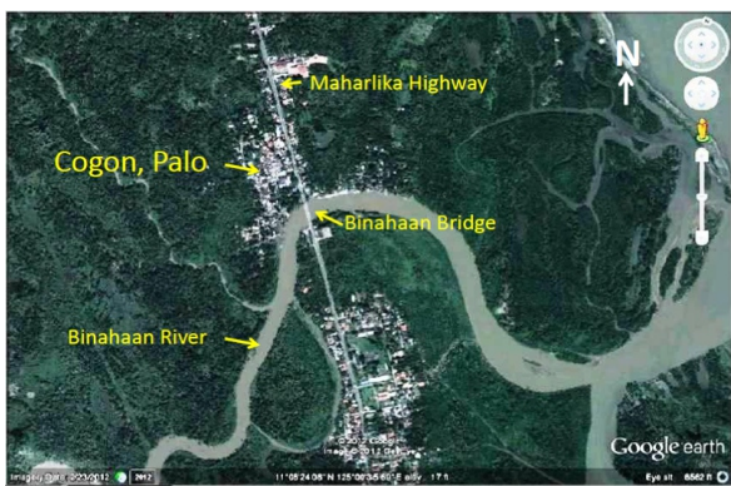

Fig.1. Location of the study site in relation to Binahaan River. 


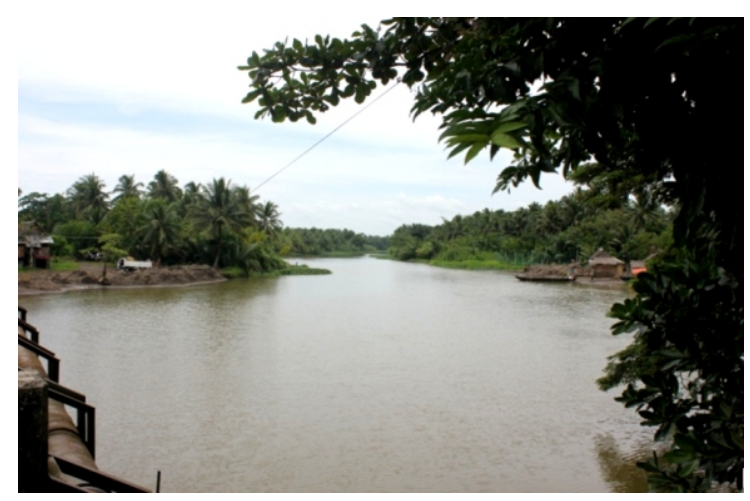

Fig. 2. Lower course of the Binahaan River.

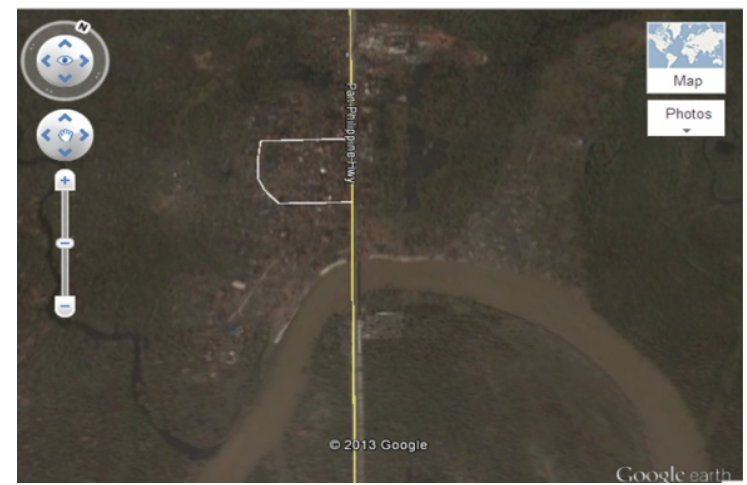

Fig. 3. Google image of the study site after typhoon Haiyan ("Yolanda").

This research followed the qualitative approach, specifically the grounded theory approach developed by Barney Glaser and Anselm Strauss (1967). The goal of this study was to generate a theoretical model that would explain the totality of a phenomenon (Frankfort-Nachmias, 1996). Hence, in this study, a theoretical model was developed to illustrate the conditions surrounding barangay residents' use of ICTs during flooding.

The snowball sampling procedure was used to identify the informants of this study (particularly those who use ICTs in their daily activities). In this sampling technique, the researcher started with a few informants. Then the sample size gradually increased as the informants recommended other informants who could potentially participate or contribute to the study (Macket al., 2005), described by Marshall (1996) as the snowball 
Use of Information and Communication Technologies in Natural Calamities

sample. The number of informants for this study was determined through theoretical sampling. In this sampling technique, interviewing of informants is stopped when the data gathered reached theoretical saturation, which means that further data gathering would only result in the same findings (Marshall and Rossman, 2011).

The data were gathered through in-depth interview with selected barangay residents. The main data gathering instrument was an unstructured in-depth interview guide. The interview questions were constructed in English and translated into Waray-waray, the dialect spoken by the informants. The interview guide was pretested afterwards. A digital audio recorder was used to record each interview with the informants.

The socio-demographic characteristics of the informants were analyzed using descriptive statistics including frequencies, totals and percentages. On the other hand, the raw data (recorded in the audio recorder) gathered from the in-depth interviews were transcribed verbatim and encoded as a written document using a word processor. Informants' access and use of ICTs during natural calamities were presented using narrative descriptions. To generate the theory about the conditions surrounding the rural residents' use of ICTs during natural calamities, the constant comparative method was applied in analyzing the transcripts. In analyzing the data, the grounded theory analysis developed by Strauss and Corbin (1998) was used. It involved the following steps: open coding, axial coding, and selective coding.

\section{RESULTS AND DISCUSSION}

The study involved 23 informants. Their background characteristics are in Table 1. Half of them were middle aged (22-45 years old); seven were old(46-59 years old); five were young(21 years old and below); and only one was a senior citizen (60 years old and above). All of them had formal school training and most had access to ICTs such as television, radio, mobile phones, internet, and landlines.

\section{Sources of disaster-related information}

Residents' sources of disaster-related information were the following: local early warning system of the barangay, mass media (television and radio), telephone (landline and mobile), and the internet.

The barangay has a flood early warning system (Figure 4) which is part of the Binahaan River Flood Early Warning System established with 
technical and financial support from the German Agency for Technical Cooperation (GTZ, now German Agency for International Cooperation or GIZ) in 2007. The system consists of monitoring stations (with rain gauges and water level sensors shown in Figure 5) installed in strategic locations in the river system that transmits data to an operations center in Palo town. The operations center then sends the warnings to the municipal operations center, which in turn disseminates the signals to the vulnerable barangays and communities through their two-way battery-operated radio and warning bells (Fig. 5).

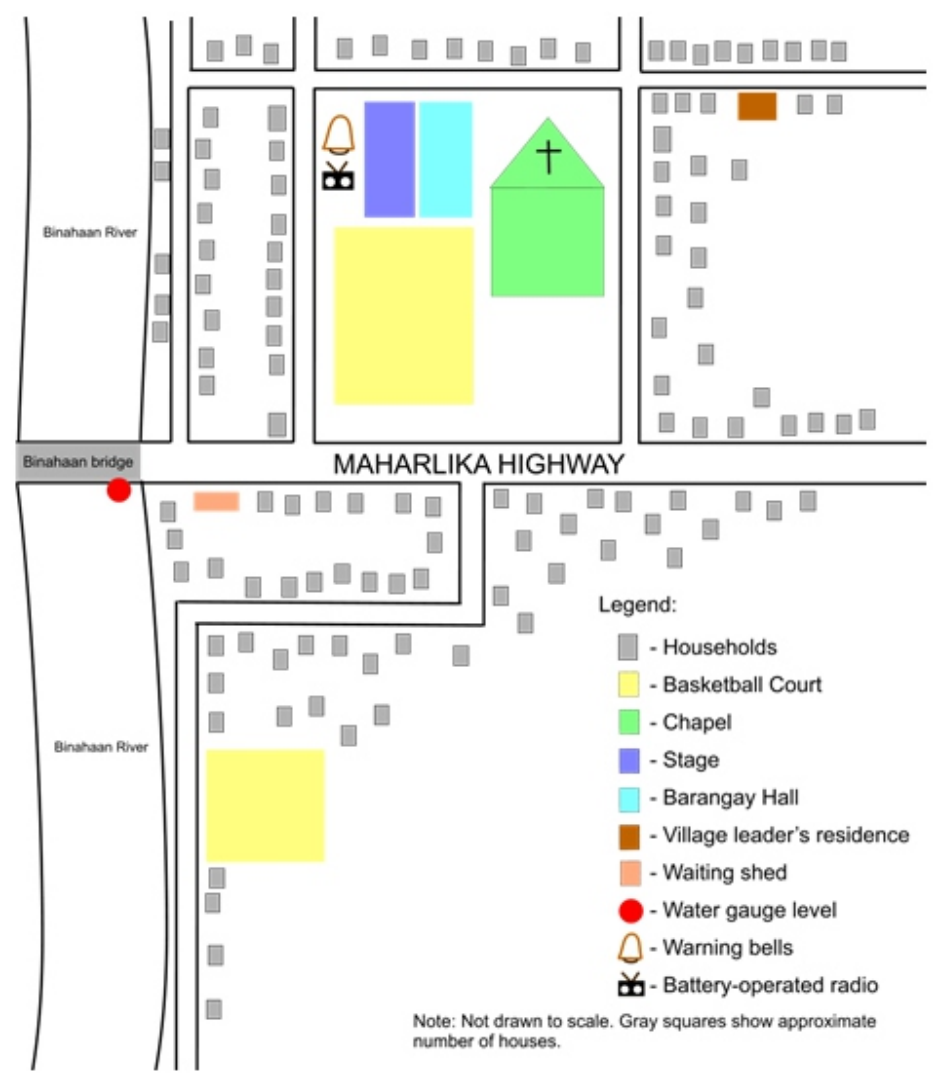

Figure 4. Location of the water gauge level, battery-operated radio and warning bell in the barangay. 
Use of Information and Communication Technologies in Natural Calamities

Table 1. Informants' socio-demographic characteristics.

\begin{tabular}{|c|c|c|}
\hline \multirow{2}{*}{$\begin{array}{ll} & \text { Variables } \\
\text { Age } & \end{array}$} & Frequency & Percentage \\
\hline & & \\
\hline Young (21 years old and below) & 5 & 21.74 \\
\hline Middle aged (22 to 45 years old) & 10 & 43.48 \\
\hline Old (46 to 59 years old) & 7 & 30.43 \\
\hline Senior citizen (60 years old and above) & 1 & 4.35 \\
\hline Total & 23 & 100 \\
\hline \multicolumn{3}{|l|}{ Sex } \\
\hline Male & 6 & 26.09 \\
\hline \multirow[t]{2}{*}{ Female } & 17 & 73.91 \\
\hline & 23 & 100 \\
\hline \multicolumn{3}{|l|}{ ICT's used daily* } \\
\hline Television & 21 & 91.30 \\
\hline Radio & 18 & 78.26 \\
\hline Mobile & 19 & 82.61 \\
\hline Landline & 2 & 8.69 \\
\hline Internet & 6 & 26.09 \\
\hline \multicolumn{3}{|l|}{ Educational Attainment } \\
\hline No schooling - no formal training & 0 & 0 \\
\hline Elementary - grades 1 to 6 & 3 & 13.04 \\
\hline High School -7 to 10 years & 10 & 43.48 \\
\hline College -11 to 14 years & 10 & $\underline{43.48}$ \\
\hline Total & 23 & 100 \\
\hline \multicolumn{3}{|l|}{ Occupation } \\
\hline Laborer, Housekeeper & 3 & 13.04 \\
\hline Driver (tricycle, bus, jeep) & 1 & 4.35 \\
\hline Security Guard & 1 & 4.35 \\
\hline Retirees & 1 & 4.35 \\
\hline Self-employed (fisherman, vendors, farmers) & 4 & 17.39 \\
\hline Housewife & 7 & 30.43 \\
\hline Student & 5 & 21.74 \\
\hline Gov. Employee & 1 & 4.35 \\
\hline Total & 23 & 100 \\
\hline
\end{tabular}

${ }^{*}$ Multiple response

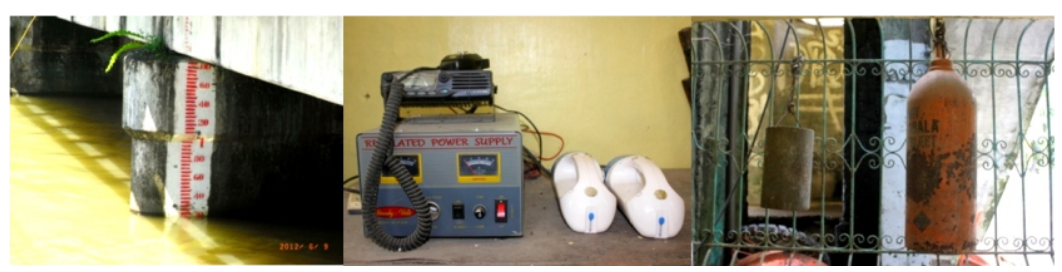

Figure 5. Water gauge level (1), two-way battery-operated radio (2) and bells (3) used for early warning in Brgy. Cogon 
According to the barangay chairman (village leader), the water gauge installed in the bridge is used as an indicator of the river level. If the river has reached the alert level, the barangay chairman and other officials immediately warn the residents of the danger. He also mentioned that their stationary two-way battery-operated radio enables them to receive updates about the situation in various parts of the river system, particularly in the municipalities of Dagami and Pastrana ${ }^{2}$, before and after the dams are opened.

The theoretical model generated by this study revealed the conditions that surround the barangay residents' use of ICTs in flooding (Fig. 6). The model illustrates the factors that affect the residents' use of ICTs in the different stages of the flooding (pre-, during, and post-disasters). The surrounding conditions are: access to information sources, specifically ICTs (reasons for good access or limited access), reasons for ICT use in the different stages of disaster, consequences of having good ICT access and use, and the consequences of limited ICT access and use.

Reasonsfor ICT access and use

Table 2 shows the respondents' reasons for getting good access to ICTs.

\section{To follow the technology trend}

According to one informant, he acquired his cellular phone in 2006 when it became a trend among people. The same was the reason for his access to the television.

"An cellphone dida han pag-uso. An akon sim, amo la ngani ada mga seven years na kay waray man karuruba. Katapos an TV, pag-abot gihap nganhi hit TV." (I got my mobile phone when it (mobile phone) became in vogue. For seven years now, I use the same sim card because it is still functional. I also bought TV when it became popular here.) [Informant 4]

Informant 2 also had the same account. Since he observed that everyone else was acquiring new technologies, he also wanted to get a hold of these tools.

“... pag-ukoy namon dinhi, four years ago. Nakikit-an kay uso naman. Kay labina it mga bag-o nagamit ba. Kun ano it uso, masubad-subad. (We 
Use of ICTs in natural calamities

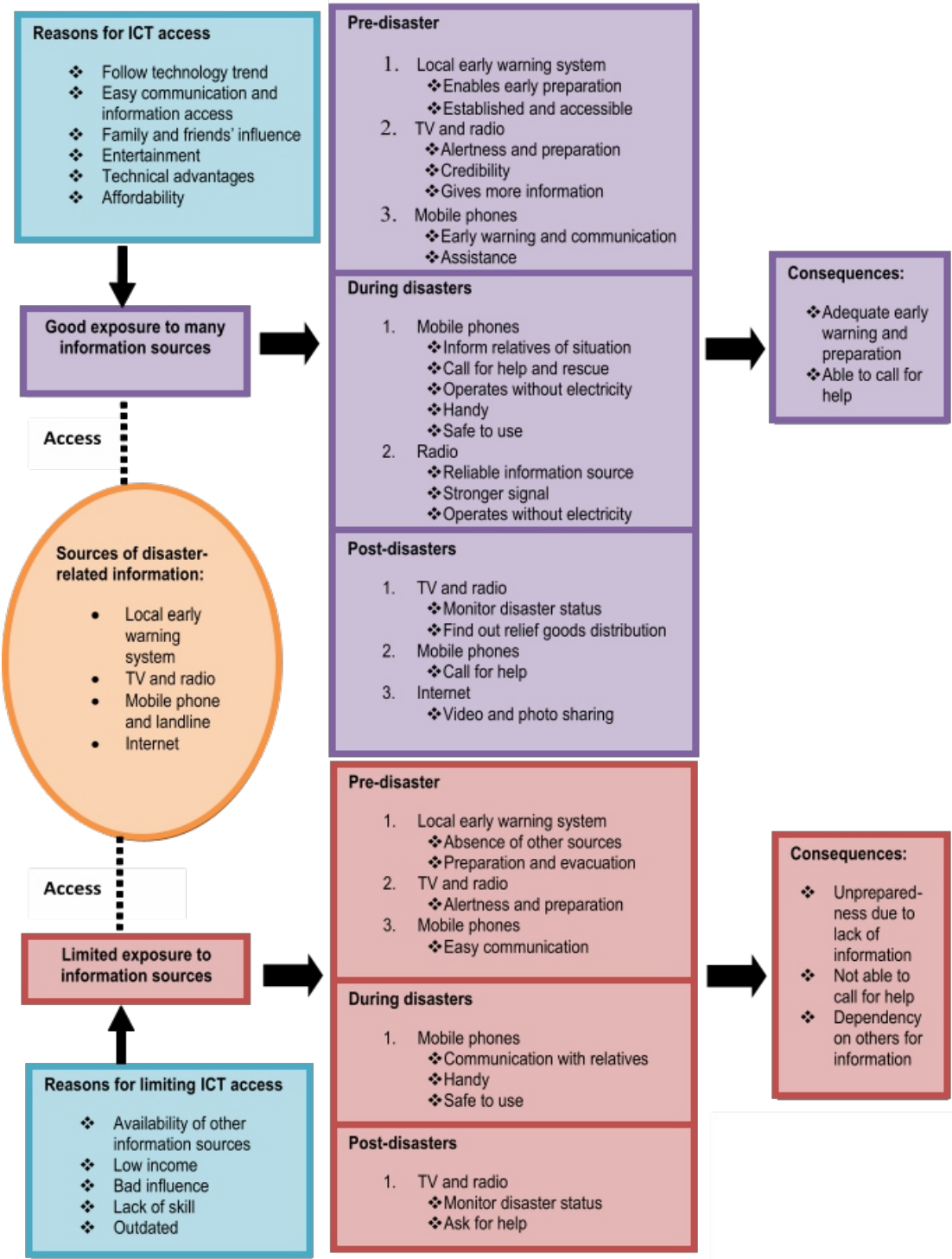

Figure 6. Theoretical model on the conditions surrounding barangay residents' use of ICTs in natural calamities. 
acquired these things when we transferred here four years ago. We observed that these new technologies became a trend among people. We just follow what is "in".)

\section{Easycommunication and information}

According to Informant 6, she was encouraged to access and use ICTs because she wanted to easily communicate with people. Her job as a barangay health worker requires her to contact her neighbors and other residents. Hence, to save the trouble of going to each and every house, she acquired a mobile phone for easier communication.

“...ginsusudoy ko man as a barangay health worker, house to house. An una nagamit hini an ak mga anak kay hira man gud an kuan. Didi na han bagan 2000, ginkuan ko kay kinukurian naman ako hit lakat-lakat kay kinahanglan, mas madali an cell phone. Madagmit nakontak talaga it cell phone, mas madali. Kontra hit matawag ka hit telepono, mayda telepono dinhi adto matawag ka pa ngadto kalsada kay kun pananglitan mauran. Kun cell phone matext ka la, mas madali." (My daughter was the first one to use this mobile phone. Since my job as a barangay health worker requires me to communicate with the other residents, I started to use mobile phones in year 2000 to make it easier for me to communicate with them (clients) instead of going from house to house. This mobile phone is also easier and more convenient to use than the telephone across the road, especially during heavy rains.)

\section{Family and friends'influence}

There were informants who were persuaded by their relatives to acquire ICTs. Some informants even got their mobile phones from their relatives.

“... diri pa ako maiha nagka-cellphone. Ginhatag la ini nira ha akon. An akon mga anak, kay hira man naghatag ini na mga gamit. Mga 2010, sugad hiton."(I recently acquired a mobile phone. My children gave this to me. It was in 2010.) [Informant 8]

"...an amon TV, gutiay pa ako hito. An akon cellphone, ginhatag la liwat han akon ate. Nga tanan namon nga gamit na phone tikang ha amon ate." 
(We've already had that television since I was a small child. My mobile phone was recently given to me by my elder sister. My elder sister was the one who gave us all of our mobile phones.) [Informant 20]

\section{Entertainment}

There were also informants who desired to be entertained thus, they acquired ICTs. According to Informant 22, she acquired ICTs for amusement.

"Radio kay music. TV libangan gihap - mga salida, cartoons, tapos kantakanta." (Radio for music. Television is also for entertainment - shows, cartoons, then for singing along.) [Informant 22]

"Akon la hiton dida, Eat Bulaga, katapos Will Time Big Time. Mga kabataan, mga cartoons." (I usually watch TV shows like Eat Bulaga and Will Time Big Time. The kids watch cartoons.) [Informant 13]

Table 2. Reasons for ICT access and use.

\begin{tabular}{ll}
\hline $\begin{array}{l}\text { Reasons for ICT access } \\
\text { and use }\end{array}$ & Description \\
\hline $\begin{array}{l}\text { To follow the } \\
\text { technology trend }\end{array}$ & $\begin{array}{l}\text { Informants reported that their reason for getting access and for using } \\
\text { ICT was to follow what is "in". Since most people have ICTs, they } \\
\text { wanted to have these tools also. }\end{array}$ \\
$\begin{array}{l}\text { Easy communication and } \\
\text { information access }\end{array}$ & $\begin{array}{l}\text { Informants said they want to access information updates easily and to } \\
\text { communicate daily with their loved ones from afar, especially during } \\
\text { emergencies. }\end{array}$ \\
$\begin{array}{l}\text { Family and friends' } \\
\text { influence }\end{array}$ & $\begin{array}{l}\text { Some informants said they were influenced by family and friends to } \\
\text { access and use ICTs. They were able to acquire ICTs from these } \\
\text { people. }\end{array}$ \\
Entertainment & $\begin{array}{l}\text { These informants accessed and used ICTs for the mere purpose of } \\
\text { entertainment such as watching TV dramas, sports, cartoons and } \\
\text { others. }\end{array}$ \\
Technical advantages & $\begin{array}{l}\text { Residents' initial access to and use of ICTs was because of the } \\
\text { technical advantages such as the availability of electricity in the area } \\
\text { and multi-purpose function of an ICT. }\end{array}$ \\
Affordability & $\begin{array}{l}\text { Some Informants were able to access and use ICTs because these are } \\
\text { already sold at a cheaper price. }\end{array}$ \\
\hline
\end{tabular}


According to Informant 15, she uses her television for entertainment especially when she feels lonely and alone at home.

For entertainment. Mamingaw naman it mga balay nga am sapit. Every time nakanhi ako, amo la it akon kay gutiay man la kami kay we're only four in the family. Amo la iton didi, waray man hira didi, most of the time waray man hira, mingaw. So an siyahan gamit namon tv. (Our television is for entertainment because it's usually quiet in this neighborhood. Every time I come home, I watch TV, since most of the time I'm all alone - there are only four of us in the family. They're not usually here and it feels lonely. That is why we use our television.) [Informant 15]

\section{Technical advantages}

Another reason for access and use of ICTs is the availability of electricity in the barangay. Informant 14 pointed out she would not have been interested to buy a television if there was no electricity.

"Kuan, magtikang dinhi, han pag-adana an kuryente. Kay nagkakuryente kami dinhi, mga 1980 ada adto, may kuryente na. Pagtikang na. Ano paman it amon karuyag hin TV, mga ano pa dida na mga appliances kun waray kuryente kay waray man adto dinhi ha amon kuryente." (We started to access the television when electricity became available here in our barangay. It was in 1980 . That was the start of it. What else would have been our motive to buy a TV or other appliances if there was no electricity?) [Informant 14]

Informant 15 emphasized that the availability of multi-purpose ICTs fascinated her. Thus, she bought one set that can be used as a desktop screen, TV set and a radio set.

"Kay amon TV naruba, human pagpalit namon TV may ada pinaintroduce ha amon na mga new innovations. Nga adi kuno na TV, dirigad 3 in 1, baga all in one naba nga puwede na nimo hiya gamiton na screen kanan desktop, tapos pwede mo butangan usb ha luyo, sasalpakan la. Tapos kuan na gihap, radio. (Our TV was destroyed. When we were buying a new one, we were introduced to new innovations - an all-inone TV. It can be used as a desktop screen and it even has a USB port. It can also be used as a radio.) 


\section{Affordability}

In the past, ICTs were still very expensive and only a few people could access it. So, the availability of affordable ICTs at present drove some of the informants to access and use it. Informant 5 said:

"Importante lalo na cellphone, pagka-ano na importante nakaka-afford naman, nakakapalit naman tag 2000. Barato naman. Pero kun han sugad hadton nga mahal, waray. Yana bisan hin-o nala nakakapalit han cell phone." (The mobile phone is important. There are already affordable mobile phones that are as cheap as \$2000 only. It is affordable unlike before when it was still very expensive that nobody could buy it. But now, anyone can buy mobile phones.)

\section{Reasons for limiting ICTaccess and use}

Informants who limited their ICT access did so because other communication sources were available, they perceived ICTs as bad, they lacked skills in operating the ICT, and their gadget was outdated (Table 2).

Table 3. Reasons for limiting ICT access and use.

\begin{tabular}{|c|c|}
\hline 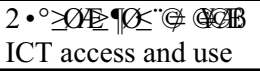 & Description \\
\hline $\begin{array}{l}\text { Availability of other } \\
\text { information sources }\end{array}$ & $\begin{array}{l}\text { Some residents said they do not regard ICTs as important because } \\
\text { there are other information and communication sources that are } \\
\text { available particularly during natural disasters. }\end{array}$ \\
\hline Low income & $\begin{array}{l}\text { There were informants who said they could not afford to maintain } \\
\text { access and use of ICTs. }\end{array}$ \\
\hline Bad influence & $\begin{array}{l}\text { According to one informant, some family problems are caused by too } \\
\text { much use of mobile phones. }\end{array}$ \\
\hline Lack of skill & $\begin{array}{l}\text { Some informants have good access to ICTs but they are not using it } \\
\text { because they find it difficult to operate. }\end{array}$ \\
\hline Outdated & $\begin{array}{l}\text { There were informants who said they do not access ICTs, particularly } \\
\text { radios, because they find these outdated or no longer "in". }\end{array}$ \\
\hline
\end{tabular}

Availability of other information sources

The interviews have shown that there were residents who regarded ICTs as not that important especially during disasters. According to them, 
there are other information sources available in their barangay. For instance, barangay officials warn residents about an upcoming disaster, hence they no longer find it necessary to access television and radio just to be informed about a disaster. Informant 20 narrated that those residents who have limited access to ICTs can still be informed about the disaster because of the early warning systems in the barangay.

"Mayda liwat hira didto pagpabagting kun may ti-arabot, mag prepare na. So waray ka TV, radio o cellphone, nakakasabot ka talaga kay nagkukuan man hira, an mga opisyal." (Barangay officials have a disaster warning system that informs residents to prepare. So, even without TV, radio, or mobile phones, one can still be informed about the disaster because of the barangay officials.) [Informant 20]

Another way of knowing that a disaster is coming is through interpersonal communication (talking with neighbors and the other residents of the barangay). As Informant 20 pointed out, some residents with limited access communicate personally with their neighbors. That is why even if they do not have enough access to ICTs, they are still informed about the disaster.

"Kay it dinhi liwat, dinhi na barangay, bisan talaga waray ka TV, radio nakakasabot ka talaga. Kay it iba nganhi, nagyayakan nala. By personal talaga, so nakakasabot ka." (Here in our community, even if we don't have access to TV or radio, we are still informed about the disaster through conversing personally with our neighbors.) [Informant 20]

\section{Lowincome}

Another reason for not being able to access and use ICTs is low income. Informant 17 said she lost her access to ICTs when she sold them to a friend so that she could earn money for the family. She found it difficult to financially maintain the television which was why she opted to sell it. Her radio was also damaged, hence at present she does not have any access to any ICT.

"Mayda ako radio, maiha na naruba. Mayda TV namon. Barato la an palit. Hulugan namon adton. Mahal la an hulugan hasta na naimpas. Pero ginbaligya liwat namon kay waray gud kwarta. Na-anugun gad ako 
Use of Information and Communication Technologies in Natural Calamities

kay maiha-ihaan na adto na TV. Pero waray man mahimo kay waray man sugad, waray pagkaon. Kay labina kay kuan, baha-baha, kailangan ko." (I had a radio set but it has long been damaged. We had a TV set which we acquired through installment; it was expensive. But we sold it because we didn't have money. I did not want to sell it because it was already with us for quite some time. But we had no choice because we did not have any money to buy food, especially in times of floods.) [Informant 17]

\section{Bad Influence}

Using ICTs are perceived as a bad influence among family members. According to Informant 3, mobile phones may be a cause for family breakup. In addition, he also emphasized that mobile phones can distract his children from their studies.

"Diria ko na gamit hito nga cell phone kay diri man maupay. Damo it impluwensya hiton, kay pwede ito mahinungdan pa karuba hit pamilya, nakaruba hiton pag study han mga anak." (I don't use the mobile phone since it brings a lot of troubles in the family. It could be a reason for family break-up and it could also distract my children from their studies.) [Informant3]

\section{Lack of skills to operate ICTs}

Analysis from the accounts of some informants also revealed that even if they have access to mobile phones, they don't often use it since they find these tools difficult to operate. They said texting is harder compared to making calls. According to Informant 13:

“...akon anak kay diri man ako maaram. Nakapot la ak hito kun tawag. (My daughter uses the mobile phone since I don't know how to use it. I only use it for making calls.)

"Makuri kay diri man ako maaram. An anak ko la an nagamit ky iya man gud ito, hiya la it maaram paggamit" (It's difficult because I don't know how to use it [cellphone]. My daughter is the only one who knows how to use it.) [Informant 16] 
Informant 11 has good access to ICTs; however, she limits her use of the mobile phone since she finds it difficult to use. According to her:

"Nakukurian ako han cellphone kay di man ako maaram pamimislit kun hain na an delete, hain an pagreply, nangangadto - narowrong send, di man ak maaram pa. Hain pipidlit kun may natawag. Hageh! Kay magoul." (For me, the mobile phone is difficult to operate. I don't know how to reply a text message. I even end up sending the message to the wrong person. I don't even know what button to press when somebody calls. It's too troublesome!)

The same is also the case for Informant 9. Although she has access to the internet, she does not use it since she perceives it as for younger generation only.

“... di man masyado importante [an internet]. Para kabataan man la ito baga." (The internet is not very useful. It is only appropriate for young people.)

\section{Outdated}

Some informants narrated that they no longer access the radio since they perceived it as outdated and not anymore trendy. Even one informant with good access said:

“...waray ko (radyo). It akon nanay mayda didto nira di-battery na radyo. Diri naman kuno nauso." (I don't have a battery-operated radio, my mother has. They say it isn't the trend anymore.) [Informant 11]

Use of ICTs in natural disasters by residents with good access to information sources

Before the occurrence of a flood, those with good access to information sources use disaster-related information from the local early warning system for the following reasons: 1) it enables early preparation, and 2) the system is already established and accessible. On the other hand, information from media sources such as TV and radio are acquired and used because of the following: 1) it can alert them of incoming disasters and allows them to prepare, 2) it is credible, and, 3) the media can give 
Use of Information and Communication Technologies in Natural Calamities

more information. Mobile phones are also used for these motives: 1) to easily warn and communicate with people, and 2) to assist those who lack access to ICTs.

During flood, informants with good access to information sources use mobile phones for these motives: 1) to inform relatives of their situation, 2) to call for help and rescue, 3) mobile phones can operate without electricity, 4) are handy, and 5) safe to use. Battery-operated radio is also preferred during disasters for these reasons: 1) it is a reliable information source, 2) it has stronger signal, and 3) it operates without electricity.

After the flood, informants with good access to information sources use the mass media to: 1) monitor its status and 2) find out relief goods distribution. On the other hand, they use mobile phones to call for assistance, while they use internet to share photos and videos of the disaster.

Use of ICTs in natural disasters by informants with limited access to information sources

From the accounts of the informants, it was discovered that those who have limited access to information sources are still informed about an approaching disaster through the local early warning system, television, radio, and mobile phones.

At the pre-disaster stage, informants with limited access to information sources use the local early warning system for the following reasons: 1) absence of other information sources, and 2) for preparation and evacuation. On the other hand, they use media sources because these alert them of incoming disasters and allow them to prepare. Also, they use mobile phones for easy communication with relatives.

During the time of the disaster, residents with limited access to information sources are only able to use mobile phones. They use these gadgets because of the following: 1) to inform relatives of their situation, 2) it is safe to use, and 3) it is handy.

After the disaster, informants with limited access to information sources only use media sources to: 1) monitor the status of the disaster, and 2) ask for help.

Restrictions to the use of ICTs during disasters

Although perceived as a useful gadget during disasters, mobile 
phones, according to some residents, still have limitations. Informant 20 emphasized that the mobile phone is useless without a load.

"Tapos an load, danay waray ako kwarta, hi ate naghahatag ha amon. Nakurian kami adto kay waray electricity tapos waray load gihap." (Sometimes I do not have money to buy load, so my elder sister gives us the money for load. During disasters, it is difficult for us because we have no electricity and we have no load.) [Informant 20]

Battery-operated ICTs also lose their battery life after hours of use. If electricity is still unavailable, laptops and mobile phones cannot be charged, hence, these tools are still useless during disasters. According to some informants:

"Danay, lowbat an laptop ngan cellphone kay diri ka man nakakasabot na ma-brownout." (Sometimes, both laptop and mobile phone have low battery level since we do not know that there will be brown out.) [Informant 10]

“... kay kun oras na hit kalamidad parong na it kuryente kay bisan kun ada it cellphone, waray nagud kun lowbat." (... in times of calamities, there is no electricity. So even if there is mobile phone, it is useless if its battery level is low.) [Informant 2]

Another limitation to the use of ICTs during disasters is the lack of time. Informants do not anymore have the opportunity to use their ICTs in times of disasters since they are already preoccupied with how they can survive the crisis. They are also keeping their ICTs to safety.

"Diri naman nagagamit pagbaha kay syempre pinanhihimos ko naman it kuan, diri na kami nakakakuan hit TV kay labi na it balay kuan pinanhihimos naman it mga gamit. (We could not use it [TV] anymore during floods since we keep our things in a safe place.) [Informant 18]

"Waray kay bagan na-tetense na kami hadto. At that time gihap, naniniguro man hadto pagkuan han mga gamit." (We did not anymore use it since we were already tense. At that time also, we were making sure that our things were safe.) [Informant 19] 
Use of Information and Communication Technologies in Natural Calamities

Restrictions to use of ICTs in post-disasters

According to some informants, the electricity is not immediately restored after the disaster. It takes about a week before the electricity comes back; hence, use of ICTs are still restricted.

"Maiha man liwat bumalik an kuryente kay may-ada man mga damage nga mga poste, it mga wire utruhon man pag-unat-unat. Mahulat na la kaayad han mga linya. Mga one week, waray kuryente."(It takes a long time for the electricity to be back because some electric posts are damaged and the lines need to be repaired. We just wait until the lines are repaired. For about one week we have no electricity.) [Informant 2]

"Magagamitan pa (an radio) kay sugad kun pagkatapos hin bagyo, diri paman ma-automatic pag kuan gud it kuryente kay bangin may-ada nag katutumba na poste, de-baterya la anay nga radio an ginagamit."(It [radio] can still be useful after the typhoon. Since the electricity is not back automatically because some electric posts have fallen over, we temporarily use a battery-operated radio.) [Informant 12]

\section{Consequences ofgood ICT access and use}

As revealed from the informants' accounts, having good access and use of ICTs in natural disasters have advantages (Table 4). These are: 1) adequate early warning and preparation, and 2) ability to call for help.

Table 4. Consequences of good ICT access and use

\begin{tabular}{|c|c|}
\hline $\begin{array}{l}\# \varnothing \mathbb{E} \pm \mu \cdot A \mathfrak{E} \bullet \geq \emptyset \| \# 4^{\circ} £ £ \cdot \gg \\
\text { and use }\end{array}$ & Description \\
\hline
\end{tabular}

Adequate early warning and preparation

Able to call for help
Informants who accessed and used ICTs during disasters were adequately warned so they were able to prepare.

Informants who access and use ICTs during disasters are able to call for help and quickly get a response. 


\section{Adequate early warning and preparation}

One advantage of using ICTs during disasters is that residents can get correct information rapidly that can enable them to prepare. According to one informant, the use of ICTs is really important during disasters since it promotes awareness; hence, there is still time for necessary preparations.

"Awareness. Kinahanglan diri pa naabot it kalamidad, nag-andam na. Kay kun oras na hit kalamidad parong na it kuryente kay bisan kun ada it cellphone, waray nagud kun lowbat. Amo gud ito preparasyon."(It is necessary to be prepared before the calamity arrives. Because during the calamity, there is no electricity and even if mobile phone is available if the battery level is low, it is of no use. That is how to prepare. ) [Informant 2]

In the case of the situation of Informant 9, she uses her mobile phone to alert her relatives about the disaster so that they may still have time to prepare.

"Cellphone gihapon kumbaga sugad parti hit calamity. Iton akon pamilya, makakasabot gihapon, gin-aano hin komunikasyon pinaagi han pagtext. Nasugad hini na "hoy! Alert!" para makasabot ngan makaandam."(Mobile phone is used in times of calamities. My family is also informed through text in order to be aware and be able to prepare.) [page 37, lines 13 to 19]

As Informant 21 mentioned, the use of mobile phones in natural calamities inform them that the dam would be opened. Through mobile phones, they are able to evacuate ahead of time.

"Dako kay marelay ha imo na adi didi dako na. Sugad didto ha Santa Fe may ko didto relative, natext ha ak na dako na daw an tubig. Masakob na ha iyo kay adto man hira harani ha dam. Nauuna man hira. Aadto man hira ha may dam, ligid. Dako na ngani it tubig didto, mapakadi na iton ha amon. Tapos sige na it am text na "hala, evacuate na kamo dida kay kami liwat didi." Dako gud na bulig it cellphone. Iton ha radio liwat, through announcer la, nga didto ha kuan dako na an tubig may mga rubber boat, sugad hini, sugad hini. Cellphone through relatives na, mga sangkay 
Use of Information and Communication Technologies in Natural Calamities

nimo na kuan nagtetext na ma-evacuate na daw kami."(It's a big help because they will relay to you that the flood is already high. For instance, I have a relative in Santa Fe who texts me if the water level is already high and is already approaching. They know because they live near the dam so they get to know ahead of us. So, when the water level is already high, we keep on texting each other and then he urges us to evacuate as soon as possible. The mobile phone is a big help. As to radio, the announcer informs us that in a particular place, the flood water is already high and there is a rubber boat. Relatives and friends also text us that we should evacuate.) [Informant 21]

Able to call for help

Informant 5 mentioned that due to mobile phone access, she is able to inform the Leyte Electric Cooperative (LEYECO) about the problems with their electric lines. She said:

"Ano man iton cellphone, maka contact ka. Sugad kun kuryente dinhi, waray pa suga, parung pa, makakatawag ngadto han LEYECO nga adi didi sugad pa, diri ba pwede buksan niyo kay may ada didi naano, nahaubos na wire, amo iton." (You are able to contact by mobile phone. For example, if there is no electricity yet, we are able to call LEYECO that here you cannot yet switch it on since there is a sagging wire. [Informant 5]

Consequences of limited access and use to ICTS

Limited access and use to ICTs had the following consequences: 1) unpreparedness due to lack of information, 2) personally calling for help, and 3) dependency on others for information.

\section{Unpreparedness due to lack of information}

The informants perceived that lack of access and use of ICTs would mean that they would not be informed of an approaching disaster. According to them, the early warning stage of the disaster is the most critical, and ICTs are really important in alerting people about a disaster. As informants said: 
"Dako nga problema kay di ka man nababaro kun may-ada kalamidad nga naabot. Di ka nababaro hit bagyo. Sing pa dako gud. Amo la ito. Makakalasan ka man kay di ka man maaram, maabot na la."'It is a big problem since you are not informed if there is an imminent calamity. You will not know if there is a typhoon. So it's a big problem. You will be caught by surprise because you are not aware.) [Informant 7]

Table 5. Consequences of limited ICT access.

\begin{tabular}{|c|c|}
\hline 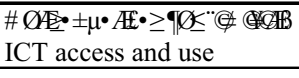 & Description \\
\hline $\begin{array}{l}\text { Unpreparedness due to } \\
\text { lack of information }\end{array}$ & $\begin{array}{l}\text { Informants with limited access to ICTs would not know what to do since } \\
\text { they are not warned about an approaching disaster. }\end{array}$ \\
\hline $\begin{array}{l}\text { Personally calling for } \\
\text { help }\end{array}$ & $\begin{array}{l}\text { Informants with limited ICT access have difficulty calling for help. Since } \\
\text { they do not have mobile phones, they personally ask people for help. }\end{array}$ \\
\hline $\begin{array}{l}\text { Dependency on others for } \\
\text { information }\end{array}$ & $\begin{array}{l}\text { Informants who had limited access to ICTs depend on the officials and other } \\
\text { residents for information about the disaster. }\end{array}$ \\
\hline
\end{tabular}

Informant 3, on the other hand, emphasized that having limited access to ICTs is tolerable since he can find other ways to secure himself and his family from the disaster.

"Kun baga, pamati ko, okay la ha akon bisan ako waray gamit na mga sugad hiton. Kay siring ko pa, ada ito hit imo kalugaringun pag-secure, nga maka gawas ka hiton nga klase nga kalamidad."(I think it is okay with me even if I do not have such things. As what I said, it depends on yourself how you will survive in such calamity.] [Informant3]

\section{Personally calling for help}

Since Informant 17 does not have any access to ICTs, she said she personally asks for help from people in times of crisis.

“...nakadto ako nangangaro hin bulig sugad kun waray na kakaunon, sugad. Amo ito." (Igo to them to ask for help when I have nothing to eat.)

Informant 13 also said that since she does not have contact with the people whom she can ask for help, she goes to them personally. Her lack of skill in using mobile phones also hinders her use of the gadget. 
Use of Information and Communication Technologies in Natural Calamities

"Letter an akon ginkuan, pero gin-pasaynan ko anay han mayor bago ako nagkadto. Personal ko gindara ngadto. Diri nira ginpaagi hin cellphone kay diri man gani ak maaram hin cellphone. Dire man ak maaram hin ira number. " I prepared a letter which I personally delivered to the mayor. But I informed first the mayor before I went to her. I do not send my request for help through mobile phone since I do not even know how to use one and I do not know their number.) [Informant 13]

\section{Dependence on othersfor information}

Based on the information provided by the informants, it appears that limited access to ICTs makes some residents dependent on neighbors and friends for means of communication and information. But some residents who lack access to ICTs see no problem with that since the barangay has an early-warning system which informs all residents about an incoming disaster.

"Problema nga diri kami mababaro? Waray man kami nakikita kay nakuan man dayun hit mga taga-barangay. Nagpapasabot man hira na may tiarabot na bagyo, may ti-arabot na baha, mahataas it tubig." (Will there be a problem since we will not be informed? We do not see such problem since barangay officials immediately announce if there is an upcoming typhoon, flood or if the water level is high.) [Informant 23]

In the case of Informant 8, although she has good access to information sources, she said she just recently acquired ICTs. Before, when she did not have any access to ICTs at all, she used to go to her neighbor's house to use their mobile phone or television. She pointed out that even if she had not acquired these technologies, it would not be a problem for her since she can still access it through her neighbors.

"Nakiki text nala ako. Nadalagan ako didto na itext daw hira kay may ada problema dinhi ha balay. Amo iton, natext kami didto. Waray ak nakikita nga problema kay nakadto man la kami didto nakikitext, nakiki-kita hit TV ha iba na balay. Namamati kun ano na kabutangan. Amo iton." (I ask somebody to text my message. I run there to ask them to text my message since there is a problem at home. That's it. I ask them to text for me. I see no problem since I can ask somebody to text. I can also watch TV in another house. Then, I listen about the happenings around.)[Informant 8] 


\section{IMPLICATIONS AND RECOMMENDATIONS}

In this study, informants' reasons for accessing and using ICTs were not primarily related to their use in times of disasters. It turned out, however, that their good access to these technologies proved useful in times of calamities (especially for early warning and preparation), during the disaster, and post-disaster response and recovery. ICTs have also proven crucial means of communication especially in warning residents of an incoming disaster. ICTs were also helpful in surviving and recovering from the disaster.

Worth noting in this community is their establishment of a water level gauge at the Binahaan River and an early warning system in the barangay hall. This early warning system alerts residents, especially those whose houses are situated from afar. However, informants said that the warning oftentimes fails to reach households that are far from the barangay hall. The use of ICTs has proven useful in this case.

The above situation suggests the need to enhance ICT access among residents and officials of disaster-prone communities. For example, since the manual methods of disseminating information, including ringing of bells and roaming around the community, in both early warning and postdisaster stages are deemed inadequate, building up the power of ICT such as the systematic use of mobile phone may be able to strengthen disaster preparedness and effective response systems in the community.

Although considered efficient, use of mobile phones to disseminate an impending disaster is often perceived as less credible by the residents. This feedback highlights the need to systematize use of mobile phones in times of disasters. One way to do this is by organizing the whole barangay into various clusters. Cluster leaders may be assigned as official sources of disaster information. Government and non-government organizations working in disaster-stricken areas may provide assistance by way of assisting cluster leaders to acquire mobile phones.

The community where this study was conducted is a naturally floodprone community, being located near the large Binahaan River. Aggravating the problem is the establishment of a dam in the upper portion of the Binahaan watershed, in Pastrana. During heavy rains, the dam releases water which causes floods in the barangay. This situation is typical of a problem resulting from a development project that has poorly considered its consequences in the neighboring communities, including flooding in the low-lying areas. This problem highlights the need to follow integrated planning in designing projects aimed to benefit various stakeholders. 
Use of Information and Communication Technologies in Natural Calamities

\section{REFERENCES}

ALVIOLA, U.B. and E.G. CAGASAN. 2008. Appropriation of Information and Communications Technologies by farmers and extension workers in Borongan, Eastern Samar. Annals of Tropical Research, 30 (1): 93-112.

CHEN, H.R. and J.G. HUANG. 2012. Exploring Learner Attitudes toward Webbased Recommendation Learning Service System for Interdisciplinary Applications. Educational Technology \& Society, 15 (2): 89-100.

FEDERICOS, M.A.S and R.S. GRAVOSO. (2012. Outcomes from learning online: The case of rice farmers and extension workers in the Philippines. Annals of Tropical Research, 34 (1), 129-146.

FRANKFORT-NACHMIAS, C. (1996). Research methods in the social sciences. New York: St. Martin's Press.

GLASER, B., A. STRAUSS. 1967. The discovery of grounded theory. USA: Aldine Transaction.

GUNAWARDENE, N., AND F. NORONHA. 2007. Introduction. In N. Gunawardene, \& F. Noronha, Communicating disasters: An Asia Pacific resource book (pp. 1-4). Bangkok, Thailand: UNDP Regional Centre in Bangkok and TVE Asia Pacific.

Borgatti, Steve. Introduction to grounded theory. 22 September 1996. 13 May 2012 <http://www.analytictech.com/mb870/introtoGT.htm>.

MACK, N., C. WOODSONG, K. MACQUEEN, G. GUEST, and E. NAME. 2005. Qualitative research methods: A data collector's field guide. North Carolina, USA: Family Health International.

MARSHALL, M. 1996. Sampling for qualitative research. Family Practice, 13(6): 522-525.

MARSHALL, C. and G. ROSSMAN. 2011. Designing qualitative research. California: Sage Publications. 
88

Asio and Cagasan

NEYLAND, E. 2011. Integrating online learning in NSW secondary schools: Three schools' perspectives on ICT adoption. Australasian Journal of Educational Technology, 27(1): 152-173.

STRAUSS, A. L., \& CORBIN, J. M. (1998). Basics of qualitative research: Techniques and produres for dveloping grounded theory. USA: Sage publications.

ZSCHAU, J. and A.N. KÜPPERS. 2003. Early warning systems for natural disaster reduction. Berlin: Springer. 